\title{
PERTUMBUHAN DAN HASIL PISANG MULI (Musa acuminata L.) DENGAN PEMBERIAN PUPUK ORGANIK GUANO
}

\author{
(Growth And Yield Muli Banana (Musa Acuminata L.) By Giving Guano Organic Fertilizer)
}

\author{
Norasyifah $^{1)}$, Muhammad Ilyas ${ }^{2)}$, Tuti Herlinawati' ${ }^{3)}$, Kani $^{4)}$ dan Mahdiannoor ${ }^{5)}$ \\ Program Studi Agroteknologi, Sekolah Tinggi Ilmu Pertanian Amuntai

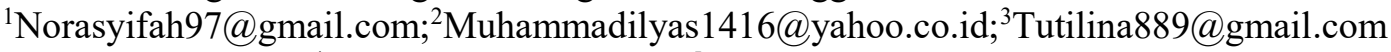 \\ ${ }^{4}$ kenkaniko@gmail.com; ${ }^{5}$ mahdi_186@yahoo.com
}

Article Submitted : 15-04-2019

Article Accepted : 17-05-2019

\begin{abstract}
Banana plants are plants that from the roots to the leaves can be used for human purposes. But the quantity and quality of production is still low, to increase production, it needs special treatment with fertilization. In addition to being a banana producer, Balangan Regency also has the potential for guano fertilizer. The purpose of this study was (i) to find out the growth and yield of muli bananas by guano organic fertilizer (ii) to get the best dose of guano organic fertilizer for optimal growth and yield of muli banana. This research was conducted in Kambiyain Village, Tebing Tinggi District, Balangan Regency, South Kalimantan Province, from March 2018 - May 2019. This experiment used a single randomized block design (RBD), the factor studied was the administration of various doses of guano fertilizer $(\mathrm{G})$ consisting of 4 levels , namely: $\mathrm{g} 1=10$ tons. $^{-1}$ is equivalent to $3.3 \mathrm{~kg}$. $1, \mathrm{~g} 2$ $=15$ tons. ha $\mathrm{h}^{-1}$ is equivalent to $4.95 \mathrm{~kg} .1, \mathrm{~g} 3=20$ tons. ha ${ }^{-1}$ is equivalent to $6,6 \mathrm{~kg} .-1, \mathrm{~g} 4=25$ tons. $\mathrm{ha}^{-1}$ is equivalent to $8.25 \mathrm{~kg}$. - 1 . Each experimental treatment consisted of 4 combinations and repeated 6 times, so that 24 experimental units were obtained. Where each experimental unit consists of 2 plants so that the whole plant has 48 plants. The results showed the growth of plant height aged 2, 3 and 4 month after planting (MAP); number of leaves aged 4 MAP; stem diameters 2, 3 and 4 showed a response to the growth of muli banana plants against various doses of guano fertilizer on podsolic fields. In generative growth only affects many fruits per comb, while at flowering time, harvest age, bunch length and many combs do not respond to the administration of various doses of guano fertilizer on podsolic fields. The best dose of guano fertilizer was g4 (25 ton.ha-1) for the growth of mauli banana plants on podsolic fields.
\end{abstract}

Keywords : Banana; muli; fertilizer; organic; guano

\section{PENDAHULUAN}

Tanaman pisang adalah suatu tumbuhan yang dari akar hingga daunnya dapat dimanfaatkan untuk kepentingan manusia. Walaupun pengembangannya oleh masyarakat sampai saat ini kebanyakan hanya ditanam sekedar pengisi lahan pada pekarangan yang kosong, atau pada tegalan-tegalan. Itulah sebabnya tanaman pisang gampang kita jumpai, dan hampir di semua sudut pekarangan rumah atau kebon di perkampungan masyarakat selalu ada terdapat tanaman pisang dari bermacam-macam jenis (Tim Bina Karya, 2008).

Pisang adalah komoditas hortikultura yang penting. Tetapi kuantitas dan kualitas 
produksinya masih rendah. Untuk meningkatkan hasil buah pisang yang diharapkan perlu adanya perlakuan khusus yang sebelumnya jarang dilakukan petani di desa tempat dimana dilaksanakan penelitian seperti dari perawatan, penanganan hama penyakit dan pemupukan.

Salah satu tindakan perawatan tanaman yang berpengaruh besar terhadap pertumbuhan tanaman dan produksi tanaman adalah pemupukan. Pemupukan bertujuan untuk menambah ketersediaan hara di dalam tanah terutama agar tanaman dapat menyerapnya sesuai dengan kebutuhan tanaman itu sendiri. Pemberian pupuk organik pada tanaman pisang tidak mutlak. Namun, bila kondisi tanahnya kurang subur atau $\mathrm{pH}$-nya rendah, sebaiknya digunakan pupuk organik untuk merangsang pertumbuhannya (Tim Bina Karya Tani, 2008).

Pupuk guano dapat memperbaiki kesuburan tanah, pupuk guano mengandung $7-$ $17 \% \mathrm{~N}, 8-15 \% \mathrm{P}$, dan $1,5-2,5 \% \mathrm{~K}$. N sangat dibutuhkan tanaman untuk mendukung pertumbuhan vegetatif tanaman. Selanjutnya $P$ merangsang pertumbuhan akar dan pembungaan, $\mathrm{K}$ terutama berperan untuk memperkuat jaringan tanaman terutama batang tanaman (Syofiani, 2017).

Menurut Mukhtaruddin et.al., (2015), bahwa tidak terjadi interaksi antara perlakuan pupuk guano dan taraf pemberian pupuk NPK terhadap kandungan $\mathrm{C}$ organik tanah subsoil di media pembibitan kelapa sawit, akan tetapi secara faktor tunggal $\mathrm{C}$ organik dipengaruhi oleh dosis pemberian pupuk guano dan pupuk NPK. Secara umum pemberian pupuk guano dapat meningkatkan rata-rata $\mathrm{C}$ organik tanah ke arah yang lebih baik.

Sebagai salah satu daerah penghasil pisang di Kalimantan Selatan pada tahun 2014 produksi pisang Kabupaten Balangan mencapai 21.839 kuintal (BPS Kabupaten Balangan 2015). Potensi pupuk guano di Kabupaten Balangan khusunya Kecamatan
Tebing Tinggi cukup baik untuk dikembangkan, ini sesuai kegiatan Balitbangda Kabupaten Balangan Tahun 2018 (Metro7 co.id, 2018). Tujuan penelitian ini adalah (i) mengetahui pertumbuhan dan hasil pisang muli dengan pemberian pupuk organik guano dan (ii) mendapatkan dosis terbaik pemberian pupuk organik guano pada pertumbuhan dan hasil pisang muli yang optimal.

\section{METODE PENELITIAN}

Penelitian ini dilaksanakan di Desa Kambiyain Kecamatan Tebing Tinggi Kabupaten Balangan Provinsi Kalimantan Selatan dari bulan Desember 2018 - April 2019. Bahan dan Alat yang digunakan dalam penelitian adalah anakan pisang muli varietas lokal, lahan podsolik merah kuning, pupuk yang digunakan adalah pupuk organik guano (pupuk dasar sekaligus pupuk perlakuan), air dan pestisida. Sedangkan alat yang digunakan untuk penelitian ini adalah linggis, parang, polybag, hand sprayer. gembor, alat pengukur, alat tulis dan kamera. Penelitian ini menggunakan Rancangan Acak Kelompok (RAK) faktor tunggal dan pengelompokan berdasarkan tinggi anakan tanaman. Faktor yang diteliti adalah pemberian berbagai dosis pupuk guano $(\mathrm{G})$ terdiri dari 4 taraf, yaitu: $\mathrm{g}_{1}=$ 10 ton. ha $^{-1}$ setara dengan $3,3 \mathrm{~kg} .^{-1}, \mathrm{~g}_{2}=15$ ton.ha ${ }^{-1}$ setara dengan $4,95 \mathrm{~kg}{ }^{-1}, \mathrm{~g}_{3}=20$ ton.ha ${ }^{-1}$ setara dengan $6,6 \mathrm{~kg} .^{-1}, \mathrm{~g}_{4}=25$ ton.ha ${ }^{1}$ setara dengan $8,25 \mathrm{~kg}^{-1}$

Setiap perlakuan percobaan sebanyak 4 kombinasi dan diulang sebanyak $6 \mathrm{kali}$, sehingga didapatkan 24 satuan percobaan. Dimana setiap satuan percobaan terdiri dari 2 tanaman sehingga keseluruhan tanaman terdapat 48 tanaman. Dan satuan percobaan terdiri dari 2 tanaman sampel yang diamati, sehingga jumlah tanaman sampel yang diamati semuanya adalah 48 tanaman. Pelaksanaan penelitian meliputi persiapan pembibitan. pembukaan lahan, pemupukan, penanaman, 
pemeliharaan tanaman, panen. pengamatan yang dilaksanakan pada percobaan ini adalah tinggi tanaman $(\mathrm{cm})$, jumlah daun (helai), diameter batang, waktu keluar jantung pisang/berbunga, panjang tandan, banyak sisir, banyak biji per sisir, panen.

Data yang diperoleh dari setiap perlakuan di uji kehomogenannya dengan uji Bartllet, apabila data homogen maka dilanjutkan dengan uji $\mathrm{F}$ pada taraf nyata $5 \%$ dan $1 \%$ untuk mengetahui pengaruh perlakuan, jika $\mathrm{F}$ hitung $>$ dari $\mathrm{F}$ tabel $5 \%$ berarti perlakuan berpengaruh nyata, dan jika $\mathrm{F}$ hitung $>\mathrm{F}$ tabel $1 \%$ berarti perlakuan berpengaruh sangat nyata. Setelah perlakuan menunjukkan pengaruh, maka dilakukan uji beda nilai tengah dengan menggunakan uji DMRT pada taraf nyata $5 \%$ untuk menentukan perlakuan terbaik (Hanafiah, 2002).

\section{HASIL DAN PEMBAHASAN}

\section{Pertumbuhan fase vegetatif}

Berdasarkan analisis ragam terdapat respon tinggi tanaman dan diameter batang pisang mauli terhadap pemberian pupuk guano pada umur 1 BST. Hal ini diduga tanaman pisang masih dalam pertumbuhan dan unsur hara yang terkandung didalam pupuk guano belum terurai dengan baik. Selain itu tanah lokasi penelitian berdasarkan hasil analisis memiliki kandungan $\mathrm{N}$ total, $\mathrm{P}$ potensial dan $\mathrm{K}$ potensial masing-masing yaitu sebesar $0,14 \%$ tergolong rendah, $8,33 \mathrm{mg} / 100 \mathrm{~g}$ tergolong sangat rendah dan $10,05 \mathrm{mg} / 100 \mathrm{~g}$ tergolong rendah serta $\mathrm{pH} \mathrm{H}_{2} \mathrm{O}$ dan $\mathrm{pH} \mathrm{KCl}$ yaitu sebesar 5,19 tergolong masam dan 4,27 tergolong sangat masam. Pupuk guano memiliki kandungan $\mathrm{N}$ total tergolong tinggi yaitu sebesar $3,713 \%$, P total yaitu sebesar $1,221 \%$ tergolong sangat rendah, $\mathrm{K}$ total tergolong sangat rendah yaitu sebesar $0,204 \%$ dan $\mathrm{pH} \mathrm{H}_{2} \mathrm{O}$ tergolong sangat masam yaitu sebesar 4.06 serta $\mathrm{C}$ - Organik yaitu sebesar $30,36 \%$ tergolong sangat tinggi. Kandungan N yang tersedia pada pupuk guano tergolong tinggi tetapi belum terdekomposisi secara sempurna oleh bakteri nitrosomonas dan nitrobacteria sehingga tidak diserap dan dimanfaatkan dengan baik oleh tanaman, selain itu kandungan $\mathrm{P}$ dan $\mathrm{K}$ pada lahan penelitian dan pada kandungan pupuk guano tergolong sangat rendah serta $\mathrm{pH}$ yang masam, sehingga penyerapan unsur hara bagi tanaman menjadi lambat.

\section{Tinggi Tanaman}

Dari hasil analisis ragam menunjukan bahwa tinggi tanaman pada umur 2, 3, dan 4 bulan setelah tanam (BST) memberikan respon terhadap pemberian dosis pupuk guano, tetapi tidak memberikan respon pada umur 1 BST. Rerata tinggi tanaman umur 1, 2, 3 dan 4 BST dapat dilihat pada Tabel 1.

Tabel 1. Hasil uji beda rata-rata tinggi tanaman pisang mauli

\begin{tabular}{ccccc}
\hline \multirow{2}{*}{ Perlakuan } & \multicolumn{4}{c}{ Rata - rata tinggi tanaman $(\mathrm{cm})$} \\
\cline { 2 - 5 } & $1 \mathrm{BST}$ & $2 \mathrm{BST}$ & $3 \mathrm{BST}$ & $4 \mathrm{BST}$ \\
\hline $\mathrm{g}_{1}$ & 96,08 & $169^{\mathrm{b}}$ & $203,42^{\mathrm{a}}$ & $257,92^{\mathrm{a}}$ \\
$\mathrm{g}_{2}$ & 96,83 & $172,92^{\mathrm{b}}$ & $226,58^{\mathrm{ab}}$ & $281,58^{\mathrm{ab}}$ \\
$\mathrm{g}_{3}$ & 85,92 & $144,83^{\mathrm{a}}$ & $251,08^{\mathrm{b}}$ & $314,83^{\mathrm{bc}}$ \\
$\mathrm{g}_{4}$ & 96,75 & $170,42^{\mathrm{b}}$ & $264,33^{\mathrm{c}}$ & $344,08^{\mathrm{c}}$ \\
\hline
\end{tabular}

Keterangan : Nilai rerata yang diikuti huruf yang sama pada kolom yang sama menunjukan perlakuan tersebut tidak berbeda berdasarkan DMRT pada taraf 5\%. 
Pada Tabel 1 terlihat pada umur 2 BST rata-rata tinggi tanaman pisang mauli pada perlakuan $\mathrm{g}_{1}, \mathrm{~g}_{2}$ dan $\mathrm{g}_{4}$ tidak berbeda, tetapi berbeda dengan perlakuan $g_{3}$. Pada umur 2 BST pemberian pupuk guano menghasilkan dosis terbaik pada perlakuan $\mathrm{g}_{1}$ yaitu 10 ton.ha 1 dan menghasilkan rata-rata tinggi tanaman tertinggi pada perlakuan $\mathrm{g}_{2}$ yaitu $172,92 \mathrm{~cm}$.

Pada umur 3 BST rata-rata tinggi tanaman pisang mauli pada perlakuan $\mathrm{g}_{4}$ berbeda dengan perlakuan $\mathrm{g}_{1}, \mathrm{~g}_{2}$ dan $\mathrm{g}_{3}$. Pada umur 3 BST pemberian pupuk guano menghasilkan dosis terbaik pada perlakuan $\mathrm{g}_{4}$ yaitu 25 ton.ha ${ }^{-1}$ dan menghasilkan rata-rata tinggi tanaman tertinggi pada perlakuan $\mathrm{g}_{4}$ yaitu $264,33 \mathrm{~cm}$.

Pada umur 4 BST rata-rata tinggi tanaman pisang mauli pada perlakuan $\mathrm{g}_{4}$ berbeda dengan perlakuan $g_{1}, g_{2}$ dan $g_{3}$. Pada umur 4 BST pemberian pupuk guano menghasilkan dosis terbaik pada perlakuan $\mathrm{g}_{4}$ yaitu 25 ton.ha $^{-1}$ dan menghasilkan rata-rata tinggi tanaman tertinggi pada perlakuan $\mathrm{g}_{4}$ yaitu $344,08 \mathrm{~cm}$.

Pada umur 2, 3 dan 4 BST pemberian pupuk guano terhadap tinggi tanaman memberikan respon sangat nyata, ini terlihat dari penambahan tinggi tanaman pada umur 2, 3 dan 4 BST. sedangkan untuk diameter batang tanaman pisang dengan pemberian pupuk guano pada umur 2 dan 3 BST memberikan respon nyata, tapi memberikan respon sangat nyata pada umur 4 BST. Pertumbuhan tinggi tanaman pisang memberikan respon sangat nyata pada umur 2 BST sampai umur 4 BST berbeda dengan pertumbuhan diameter batang yang secara bertahap semakin lama semakin tersedia unsur hara bagi tanaman dan memberi respon pada pertumbuhan diameter batang. Hal ini kandungan $\mathrm{N}$ dalam tanah sudah tersedia bagi tanaman. Pemberian bahan organik ke dalam tanah akan mengalami penguraian dan membebaskan N. Menurut Hakim et. al., (2011) dalam Syofiani dan Oktabriana (2017), pemberian bahan organik ke dalam tanah mengalami proses dekomposisi yang mampu menghasilkan nitrogen. Bahan organik adalah sumber $\mathrm{N}$ utama dalam tanah. Bahan organik akan dirombak dengan bantuan mikroba tanah menjadi senyawa amina (aminisasi). Senyawa amina akan menjadi amonium (ammonifikasi), dan selanjutnya amonium diubah menjadi nitrit dan nitrat (nitrifikasi). Melalui mekanisme tersebut, $\mathrm{N}$ yang terkandung di dalam guano akan dibebaskan ke dalam tanah, sehingga tersedia bagi tanaman.

Unsur $\mathrm{N}$ yang diserap oleh akar digunakan untuk pertumbuhan secara keseluruhan, khususnya batang, cabang dan daun. Pemberian pupuk organik yang mengandung unsur $\mathrm{N}$ akan mendorong dan mempercepat pertumbuhan dan pertambahan tinggi tanaman. Pertumbuhan tinggi tanaman berlangsung pada fase pertumbuhan vegetatif. Fase pertumbuhan vegetatif tanaman berhubungan dengan tiga proses penting yaitu pembelahan sel, pemanjangan sel, dan tahap pertama dari diferensiasi sel. Ketiga proses tersebut membutuhkan kabohidrat, karena karbohidrat yang terbentuk akan bersenyawa dengan persenyawaan-persenyawaan nitrogen untuk membentuk protoplasma pada titik-titik tumbuh yang akan mempengaruhi pertambahan tinggi tanaman. Ketersediaan karbohidrat dibentuk dalam tanaman dipengaruhi oleh ketersediaan hara bagi tanaman tersebut (Mardianto, 2014 dalam Syofiani dan Oktabriana, 2017).

\section{Jumlah Daun}

Dari hasil analisis ragam menunjukan bahwa jumlah daun pada umur 4 BST memberikan respon terhadap pemberian dosis pupuk guano, tetapi tidak memberikan respon pada umur 1, 2 dan 3 BST. Rerata jumlah daun umur 1, 2, 3 dan 4 BST dapat dilihat pada Tabel 2. 
Tabel 2. Hasil uji beda rata-rata jumlah daun pisang mauli

\begin{tabular}{ccccc}
\hline \multirow{2}{*}{ Perlakuan } & \multicolumn{5}{c}{ Rata - rata jumlah daun (helai) } \\
\cline { 2 - 5 } $\mathrm{g}_{1}$ & 1 BST & BST & 3 BST & 4 BST \\
\hline $\mathrm{g}_{2}$ & 7,58 & 10,42 & 10,17 & $10,92^{\mathrm{a}}$ \\
$\mathrm{g}_{3}$ & 7,92 & 10,42 & 10,83 & $11^{\mathrm{a}}$ \\
$\mathrm{g}_{4}$ & 6,92 & 9,75 & 11 & $11,67^{\mathrm{b}}$ \\
\hline
\end{tabular}

Keterangan : Nilai rerata yang diikuti huruf yang sama pada kolom yang sama menunjukan perlakuan tersebut tidak berbeda berdasarkan DMRT pada taraf 5\%.

Pada Tabel 2 terlihat pada umur 4 BST rata-rata jumlah daun pisang mauli pada perlakuan $\mathrm{g}_{1}$ dan $\mathrm{g}_{2}$ tidak berbeda, tetapi berbeda dengan perlakuan $\mathrm{g}_{3}$ dan $\mathrm{g}_{4}$. Pada umur 4 BST pemberian pupuk guano menghasilkan dosis terbaik pada perlakuan $\mathrm{g}_{3}$ yaitu 20 ton.ha ${ }^{1}$ dan menghasilkan rata-rata jumlah daun tertinggi pada perlakuan $\mathrm{g}_{4}$ yaitu 11,75 helai.

Berdasarkan hasil analisis ragamnya terlihat bahwa jumlah daun pisang mauli dengan pemberian pupuk guano memberikan respon sangat nyata pada umur 4 BST tetapi tidak memberikan respon pada umur 1, 2 dan 3 BST. Hal ini diduga tidak tersedianya unsur hara $\mathrm{P}$ dan $\mathrm{K}$ sedangkan unsur $\mathrm{N}$ hanya mengarah pada maristem atau pada bagian pucuk. karena kondisi lahan penelitian yang masam dan kandungan $\mathrm{pH}$ pupuk guano tergolong sangat masam sehingga $\mathrm{N}$ tidak diserap dengan baik oleh tanaman walaupun kandungan unsur hara $\mathrm{N}$ pada pupuk guano tergolong tinggi. Kekurangan unsur hara $\mathrm{N}$ yang tidak diserap baik oleh tanah dengan maksimal sehingga mengganggu pertumbuhan, selain itu juga tanaman yang kekurangan unsur $\mathrm{N}$ tidak dapat memenuhi kebutuhan tanaman untuk mencapai tingkat produksi yang optimal sehingga pertumbuhan tanaman juga akan terganggu (Rochmadhona, 2017). Selain Unsur $\mathrm{N}$ tidak diserap dengan baik, kandungan $\mathrm{C}$ organik pada pupuk guano sangat tinggi yaitu $30,36 \%$ tetapi tidak terombak dengan baik karena kandungan $\mathrm{pH}$ pada tanah lokasi penelitian dan $\mathrm{pH}$ pada pupuk guano yang sama- sama sangat masam. Menurut Zimmerman, (1997) dalam Sukaryorini et al., (2016), bahan organik akan mengalami proses dekomposisi secara bertahap, dengan adanya beberapa kandungan hara di dalam bahan organik akan melepas ikatan karbon yang kompleks menjadi ikatan - ikatan sederhana. Akibat penggunaan kandungan unsur hara karbon oleh mikroorganisme mendapatkan sumber energi untuk keperluan hidupnya melalui proses respirasi. Sehingga bahan organik yang telah mengalami proses dekomposisi akan mempunyai kandungan unsur hara karbon semakin meningkat. Akan tetapi ada pula faktor yang dapat mempengaruhi proses penguraian antara lain suhu, iklim dan $\mathrm{pH}$. Dengan mempunyai suhu berkisar $28^{\circ} \mathrm{C}-31^{\circ} \mathrm{C}$ mampu melakukan perombakan yang baik, sehingga semakin tinggi kandungan karbon yang dilepas melalui udara maka akan semakin tinggi pula perkembangbiakkan mikroorganisme pada metabolisme karbohidrat dalam tanah. Pada umur 4 BST memberikan respon sangat nyata terhadap jumlah daun. Hal ini diduga $\mathrm{pH}$ pada kandungan pupuk guano menjadi meningkat dikarenakan mikroorganisme perombak bahan organik dalam tanah dapat diuraikan dengan baik. Pengaruh pemberian bahan organik dapat meningkatkan $\mathrm{pH}$ tanah meskipun peningkatannya masih dalam kategori masam. Tingkat kemasaman tanah akibat dari pemberian bahan organik bergantung pada tinkat kematangan dari bahan organik yang 
diberikan, batas kadaluarsa dari bahan organik dan jenis tanahnya. Jika penambahan bahan organik yang masih belum matang akan penyebabkan lambatnya proses peningkatan $\mathrm{pH}$ tanah dikarenakan bahan organik masih belum terdekomposisi dengan baik dan masih melepaskan asam-asam organik (Suntoro, 2003 dalam Afandi et. al., 2015 ). Selain $\mathrm{pH}$ meningkat kandungan unsur hara $\mathrm{P}$ dan $\mathrm{K}$ mulai tersedia ini terlihat dari pertumbuhan daun berpengaruh pada umur 4 BST.

Wahida dan Suryaningsih (2016), menyatakan bahwa pemupukan $\mathrm{P}$ akan meningkatkan percabangan akar dan perkembangan akar lateral serta ini akan meningkatkan penggunaan dan pengangkutan $\mathrm{P}$ oleh tanaman. Dengan meningkatnya akar maka pertumbuhan trubus juga akan semakin baik karena suplai nutrisi ke bagian batang dan daun juga menjadi tercukupi. Sutiyoso (2008) dalam Wahida dan Suryaningsih (2016), menjelaskan bahwa fosfor (P) dapat mengubah energi cahaya matahari menjadi energi kimia melalui proses fotosintesis asimilasi CO maka karbohidrat akan tersedia dalam jumlah banyak, karbohidrat akan disintesis dengan unsur $\mathrm{N}$ dan $\mathrm{S}$ menjadi protein. Dengan demikian, pembentukan sel, jaringan dan organ akan menjadi pesat sehingga pertumbuhan tanaman akan cepat. Kalium (K) memiliki fungsi mengatur translokasi hasil asimilat ke bagian-bagian tanaman yang membutuhkan sehingga pertumbuhan seluruh tanaman akan maju secara merata. Bila tamanam kekurang K, maka banyak proses tidak berjalan dengan baik, misalnya terjadi kumulasi karbohidrat, menurunnya kadar pari, dan akumulasi senyawa nitrogen dalam tanaman. Bila kegiatan enzim terhambat, maka akan terjadi penimbunan senyawa tertentu karena prosesnya menjadi terhenti.

Menurut Marpaung (2014), pemberian pupuk organik padat berperan dalam pertumbuhan vegetatif tanaman, dimana dengan pemberian pupuk organik maka tanah sebagai media tumbuh tanaman dapat diperbaiki sehingga penyerapan unsur hara oleh tanaman semakin meningkat dan dapat dimanfaatkan untuk pertumbuhan dalam pembentukan daun.

\section{Diameter Batang}

Dari hasil analisis ragam menunjukan bahwa diameter batang pada umur 2, 3, dan 4 BST memberikan respon terhadap pemberian dosis pupuk guano, tetapi tidak memberikan respon pada umur 1 BST. Rerata diameter batang umur 1, 2, 3 dan 4 BST dapat dilihat pada Tabel 3.

Tabel 3. Hasil uji beda rata-rata diameter batang pisang mauli

\begin{tabular}{ccccc}
\hline \multirow{2}{*}{ Perlakuan } & \multicolumn{4}{c}{ Rata - rata diameter batang $(\mathrm{cm})$} \\
\cline { 2 - 5 } & 1 BST & 2 BST & 3 BST & 4 BST \\
\hline $\mathrm{g}_{1}$ & 3,38 & $5,53^{\mathrm{b}}$ & $6,59^{\mathrm{a}}$ & $8,31^{\mathrm{a}}$ \\
$\mathrm{g}_{2}$ & 3,26 & $5,71^{\mathrm{b}}$ & $7,21^{\mathrm{a}}$ & $8,90^{\mathrm{a}}$ \\
$\mathrm{g}_{3}$ & 2,98 & $4,69^{\mathrm{a}}$ & $8,04^{\mathrm{b}}$ & $9,68^{\mathrm{a}}$ \\
$\mathrm{g}_{4}$ & 3,39 & $5,42^{\mathrm{b}}$ & $8,35^{\mathrm{b}}$ & $10,38^{\mathrm{b}}$ \\
\hline
\end{tabular}

Keterangan : Nilai rerata yang diikuti huruf yang sama pada kolom yang sama menunjukan perlakuan tersebut tidak berbeda berdasarkan DMRT pada taraf 5\%.

Pada Tabel 3 terlihat pada umur 2 BST rata-rata diameter batang pisang mauli pada perlakuan $\mathrm{g}_{1}, \mathrm{~g}_{2}$ dan $\mathrm{g}_{4}$ tidak berbeda, tetapi berbeda dengan perlakuan $g_{3}$. Pada umur 2 
BST pemberian pupuk guano menghasilkan dosis terbaik pada perlakuan $\mathrm{g}_{1}$ yaitu 10 ton.ha ${ }^{1}$ dan menghasilkan rata-rata diameter batang tertinggi pada perlakuan $\mathrm{g}_{2}$ yaitu $7,21 \mathrm{~cm}$.

Pada umur 3 BST rata-rata diameter batang pisang mauli pada perlakuan $\mathrm{g}_{4}$ berbeda dengan perlakuan $g_{1}, g_{2}$ dan $g_{3}$. Pada umur 3 BST pemberian pupuk guano menghasilkan dosis terbaik pada perlakuan $\mathrm{g}_{3}$ yaitu 20 ton.ha ${ }^{1}$ dan menghasilkan rata-rata diameter batang tertinggi pada perlakuan $\mathrm{g}_{4}$ yaitu $8,35 \mathrm{~cm}$.

Pada umur 4 BST rata-rata diameter batang pisang mauli pada perlakuan $\mathrm{g}_{4}$ berbeda dengan perlakuan $\mathrm{g}_{1}, \mathrm{~g}_{2}$ dan $\mathrm{g}_{3}$. Pada umur 4 BST pemberian pupuk guano menghasilkan dosis terbaik pada perlakuan $\mathrm{g}_{4}$ yaitu 25 ton.ha ${ }^{-}$ ${ }^{1}$ dan menghasilkan rata-rata diameter batang tertinggi pada perlakuan $\mathrm{g}_{4}$ yaitu $10,38 \mathrm{~cm}$.

Pertumbuhan diameter batang tanaman masih terjadi pada saat akhir masa vegetatif, hal ini karena penyerapan unsur hara oleh tanaman tidak dapat diserap sekaligus untuk pertumbuhan tinggi dan diameter batang. Pada awal pertanaman unsur hara akan tertuju pada pertumbuhan tinggi tanaman dan saat mendekati masa akhir vegetatif unsur hara akan diserap untuk pertumbuhan diameter batang. Unsur hara N, P, K merupakan unsur hara makro yang banyak diserap tanaman terutama pada fase vegetatif (Puspadewi et. al., 2016). Menurut Hidayati (2009) dalam Puspadewi et. al., (2016), pupuk organik juga memiliki peranan dalam mendukung pertumbuhan vegetatif tanaman. Tanah dengan bantuan kandungan bahan organik yang tinggi dapat dipastikan mempunyai sifat fisik, kimia dan biologi tanah yang lebih baik.

\section{Pertumbuhan Fase Generatif}

Berdasarkan analisis ragam peubah pengamatan terlihat bahwa waktu keluar jantung pisang/berbunga, umur panen, panjang tandan dan banyak sisir tidak memberikan respon terhadap pemberian pupuk guano, kecuali pada peubah pengamatan banyak buah pisang per sisir memberikan respon terhadap pemberian pupuk guano.

\section{Waktu keluar jantung pisang/berbunga}

Berdasarkan hasil analisis ragam menunjukan bahwa waktu keluar jantung pisang/berbunga, panjang tandan, banyak sisir, dan umur panen tidak memberikan respon terhadap pemberian pupuk guano, namun dari hasil analisis ragam menunjukan bahwa banyak buah per sisir memberikan respon terhadap pemberian dosis pupuk guano. Rerata banyak buah per sisir dapat dilihat pada Tabel 4 .

Tabel 4 . Hasil uji beda rata-rata banyak buah persisir (buah)

\begin{tabular}{cc}
\hline Perlakuan & Banyak buah per sisir (buah) \\
\hline $\mathrm{g}_{1}$ & $55,25^{\mathrm{a}}$ \\
$\mathrm{g}_{2}$ & $70,6^{\mathrm{a}}$ \\
$\mathrm{g}_{3}$ & $69,4^{\mathrm{a}}$ \\
$\mathrm{g}_{4}$ & $93^{\mathrm{b}}$ \\
\hline
\end{tabular}

Keterangan : Nilai rerata yang diikuti huruf yang sama pada kolom yang sama menunjukan perlakuan tersebut tidak berbeda nyata berdasarkan DMRT pada taraf $5 \%$.

Pada Tabel terlihat rata-rata banyak buah persisir pisang muli pada perlakuan $\mathrm{g}_{1}, \mathrm{~g}_{2}$ dan $g_{3}$ tidak berbeda, tetapi berbeda dengan perlakuan $\mathrm{g}_{4}$. Pemberian pupuk guano menghasilkan dosis terbaik pada perlakuan $\mathrm{g}_{4}$ yaitu 25 ton.ha ${ }^{-1}$ dan menghasilkan rata-rata banyak buah per sisir pada perlakuan $g_{4}$ yaitu 93 buah. 
Masing-masing jenis tumbuhan memiliki kemampuan yang berbeda dalam hal berbunga. Kemampuan tersebut dapat disebabkan faktor internal, seperti sifat genetik dan faktor eksternal yang pada umumnya disebabkan oleh pengaruh lingkungan. Perubahan struktur tegakan, kepadatan populasi dan perubahan lingkungan mikro dapat mempengaruhi berbunga dan berbuah dan produksi benih. Saat ini kemampuan berbunga dan berbuah telah dapat diintervensi dengan melakukan stimulasi pembungaan. Untuk beberapa jenis tertentu, stimulasi pembungaan dapat dilakukan dengan pemupukan (Nurhasybi, et.al., 2010).

Berdasarkan hasil analisis tanah podsolik di Desa Kambiyain Kecamatan Tebing Tinggi Kabupaten Balangan. Kandungan $\mathrm{P}$ potensial $8,33 \mathrm{mg} / 100 \mathrm{~g}$ sangat rendah, dan hasil analisis pupuk guano menunjukan $\mathrm{P}$ total 1,22 \% sangat rendah, jadi kandungan $\mathrm{P}$ pada tanah dan pupuk yang digunakan masih rendah. Hal itulah yang menyebabakan proses berbunga menjadi lambat. Pada fase vegetatif, tanaman lebih banyak membutuhkan pupuk dengan kadar nitrogen tinggi. Pada fase generatif, unsur fosfor dibutuhkan dalam jumlah lebih besar dibandingkan dengan unsur hara makro lainnya.

Peranan unsur fosfor $(\mathrm{P})$ pada pertanian fosfor (P) merupakan unsur hara yang diperlukan dalam jumlah besar (hara makro). Jumlah fosfor dalam tanaman lebih kecil dibandingkan Nitrogen dan Kalium. Tetapi fosfor dianggap sebagai kunci kehidupan (Key of life). Unsur ini merupakan komponen tiap sel hidup dan cenderung terkonsentrasi dalam biji dan titik tumbuh tanaman. Unsur P dalam phospat adalah (Fosfor) sangat berguna bagi tumbuhan karena berfungsi untuk merangsang pertumbuhan akar terutama pada awal-awal pertumbuhan, mempercepat pembungaan, pemasakan biji dan buah (Torus, 2012).
Pada saat memasuki fase generatif, kebutuhan unsur hara sangat diperlukan bagi perkembangan buah dan biji, terutama unsur hara fosfor $(\mathrm{P})$. Fosfor sangat dibutuhkan oleh tanaman pada fase generatif, karena fosfor dapat mempercepat masa pembungaan dan pemasakan buah, biji atau gabah, selain itu sebagai penyusun lemak dan protein dan berfungsi untuk pengangkutan energi hasil metabolisme dalam tanaman. (Menurut Sutedjo 2010 dalam Qibtyah 2015). Saat keluar bunga pada tanaman sangat dipengaruhi oleh unsur fosfor yang mampu diserap oleh tanaman. didalam tanah fungsi $P$ bagi tanaman adalah sebagai zat pembangun dan terikat dalam senyawa-senyawa organik, sebagai zat pembangun $\mathrm{P}$ terpencar-pencar dalam tubuh tanaman, bagian tubuh tanaman yang berkaitan dengan pembiakan generatif, seperti pembentukan bunga dan buah, jadi dalam proses pembentukan bunga banyak membutuhkan P.

Karateristik fosfor yaitu, fosfor bergerak lambat dalam tanah; pencucian bukan masalah, kecuali pada tanah yang berpasir. Fosfor lebih banyak berada dalam bentuk anorganik dibandingkan organik. Di dalam tanah kandungan $\mathrm{F}$ total bisa tinggi tetapi hanya sedikit yang tersedia bagi tanaman.Tanaman menambang fosfor tanah dalam jumlah lebih kecil dibandingkan nitrogen dan K (Torus, 2012).

Seharusnya pemupukan diberikan secara rutin 2 kali dalam setahun yang dilakukan 6 bulan setelah tanam. Waktu pemupukan dibagi menjadi pemupukan dasar dan pemupukan susulan (Sipendik Team, 2014). Penambahan pupuk ini harus dilakukan karena tidak terjadi keseimbangan jumlah hara dalam tanah di mana jumlah hara akan terus berkurang dari waktu ke waktu. Berkurangnya jumlah hara dalam tanah atau media tanam dapat terjadi disebabkan karena beberapa faktor : pertama karena sebagian besar hara akan terikut bersama hasil panen yang diambil 
dari tanaman, kedua karena efisiensi penyerapan hara yang cukup rendah oleh tanaman akibat cara atau aplikasi pemberian pupuk yang salah, ketiga karena faktor kehilangan hara akibat proses penguapan dan pencucian hara oleh air pengairan/penyiraman, dan keempat karena sebagian pupuk terjerap dan terikat (fixation) di dalam partikel tanah sehingga menjadi tidak tersedia bagi tanaman. Kekurangan unsur hara akan menghambat pertumbuhan dan perkembangan tanaman, karena hara bagi tanaman ibarat makanan pada manusia (Leira, 2012).

\section{Panjang Tandan}

Panjang tandan pisang dipengaruhi oleh proses pembungaan tanaman pada awal pertanaman unsur hara akan tertuju pada pertumbuhan tinggi tanaman dan saat mendekati masa akhir vegetatif unsur hara akan diserap untuk pertumbuhan vegetatif. Unsur hara N, P, K merupakan unsur hara makro yang banyak diserap tanaman terutama pada fase vegetatif (Puspadewi et. al., 2016). Menurut Hidayati (2009) dalam Puspadewi et. al., (2016).

Faktor-faktor yang mempengaruhi besar kecilnya tandan pisang adalah : (1) kondisi tanah, kondisi tanah yang subur tentu saja akan berpengaruh tehadap besar dan Panjang tandan. Sebaliknya tanah yang kurang subur akan mengakibatkan tandan pisang kecil dan pendek. (2) iklim, bila bunga keluar saat musim hujan, tandan akan lebih besar dan panjang disbanding pada musim kemarau. (3) jenis pisang, masing- masing jenis pisang memiliki sifat yang berbeda, ada yang bertandan panjang ada juga yang brtandan pendek (4) kecepatan tumbuh tanaman, pisang yang pada waktu mudanya tumbuh sengan baik biasanya akan menghasilkan tandan yang lebih baik dibandingkan tanaman pisang yang saat mudanya berukuran kecil (Suyanti dan Supriyadi, 2008).
Terdapat beberapa faktor yang menyebabkan melambatnya pertumbuhan generatf pisang, yaitu penurunan status kesuburan tanah serta adanya tekanan hama dan penyakit. Terkait dengan penurunan status kesuburan tanah, ternyata terdapat korelasi antara tingkat serangan hama dan penyakit dengan status hara tanah. Status hara tanah yang buruk menstimulasi munculnya serangan hama dan penyakit. Pada beberapa kasus, status hara tanah yang buruk memperparah efek yang ditimbulkan oleh serangan hama dan penyakit. Berdasarkan kondisi tersebut, perbaikan status kesuburan tanah dapat dimanfaatkan untuk menangkal pengaruh negatif dari serangan hama dan penyakit (Prihatini, 2012).

Kalium dibutuhkan tanaman untuk menjaga turgiditas dan potensial osmosis sel. Dengan jumlah kalium yang cukup, dinding sel akan lebih tebal dan stabil. Hal ini berpengaruh terhadap ketahanan terhadap serangan hama dan penyakit. Selain itu, dengan jumlah kalium yang cukup, buah dan sayur mempunyai umur simpan yang lebih panjang (Bennett, 1996). Kalium merupakan unsur yang paling banyak terdapat dalam pisang, baik bagian vegetatif maupun generatifnya. Hal ini mengakibatkan diperlukannya pemupukan kalium yang tepat bagi tanaman pisang (Putro, 2008).

Tanaman memerlukan unsur hara yang lengkap agar dapat tumbuh dengan baik dan menghasilkan produk yang berkualitas. Pemenuhan unsur hara kebutuhan tanaman merupakan hal yang mutlak dilakukan, karena ketersediaan unsur hara di alam sangat terbatas, dan semakin berkurang karena telah terserap oleh tanaman (Prihatini, 2012).

\section{Banyak Sisir}

Dengan semakin panjang tandan pisang maka semakin banyak jumlah sisir pada pisang, jadi panjang tandan pisang mempengaruhi banyaknya sisir yang dihasilkan oleh tanaman pisang. Ketersedian unsur hara sangat dibutuhkan sampai memasuki fase generatif 
untuk memenuhi unsur hara pada tanaman agar tidak terjadi kekurangan suplai unsur hara.

Pada suatu titik waktu, sisir buah buah pisang yang terbentuk akan berhenti muncul, tetapi tangkai jantung akan terus memanjang. Bila Panjang tangkai jantung pisang telah mencapai $15-25 \mathrm{~cm}$, pertanda sudah saatnya jantung pisang dipotong karena sudah tidak bias menghasilkan sisir buah lagi. Pemotongan jantung bisa menambah berat buah sekitar 5\% dibandingkan dengan tidak dipotong (Suyanti dan Supriyadi, 2008).

Pisang membutuhkan unsur hara yang banyak untuk pertumbuhan tanaman dan produksi buah. Menurut Nakasone dan Paull (1998) sebagian besar unsur hara tersebut diperoleh dari tanah dan pembusukan bahan tanaman serta sisanya dapat ditambahkan melalui pemberian bahan organik dan pupuk. Kebutuhan rata-rata tanaman pisang terhadap unsur hara adalah $388 \mathrm{~kg} / \mathrm{ha}$ nitrogen $(843.48$ $\mathrm{kg} /$ ha Urea dengan $46 \% \mathrm{~N}$ ), $52 \mathrm{~kg} /$ ha fosfor (144.44 kg/ha SP-36 dengan 36\% P2O5) dan 1 $438 \mathrm{~kg} / \mathrm{ha}$ kalium $(2876 \mathrm{~kg} / \mathrm{ha} \mathrm{KCl}$ dengan 50\% K2O) (Putro, 2008).

\section{Banyak Buah Per Sisir}

Peubah pengamatan banyak buah pisang per sisir memberikan respon terhadap pemberian pupuk guano. Walaupun pada waktu berbunga, umur panen, panjang tandan dan banyak sisir tidak memberikan respon pada pemberian pupuk guano.

Pertumbuhan dan perkembangan buah yang biasanya dengan fertilasi, disebut set buah. Set buah dikaitkan dengan sejumlah peristiwa fisiologis, termasuk pertumbuhan dan pembungaan buah yang cepat dan penuaan bunga. Dalam studi mengenai anyeliner ' white Sim' (Nicholas, 1971) dua bahan pertumbuhan, asam 2-kloroetilfosforat (etefon) dan asam 2,4-diklorofenoksiasetat (2,4-D). Menyebabkan penuaan bunga yang dipercepat bersamaan dengan perkembangan buah , mungkin dengan cara merangsang produksi
IAA, yang membebaskan etilan yang terikat dalam bunga. Bunga yang dibuahi menghasilkan empat hingga lima kali lipat etilin sebanding dengan bunga yang tidak dibuahi. Serbuk sari mengandung auksin yang memicu reaksi yang bersangkutan dengan set buah. Suatu buah yang sedang tumbuh merupakan sumber utama auksin bagi dirinya sendiri (Gardner et.al., 1991).

Berdasarkan hasil analisis pupuk guano yang digunakan kandungan unsur $\mathrm{N}$ yang tinggi dibandingkan unsur $\mathrm{P}$ dan $\mathrm{K}$ menyebabkan jumlah buah yang dihasilkan menjadi banyak, dimana unsur $\mathrm{N}$ masih tersedia sampai pada fase kepada gneratif. Banyak tidaknya jumlah sisir tidak mempengaruhi jumlah buah, karena semakin banyak sisir tidak menentukan semakin banyak jumlah buah yang dihasilkan. Robinson (1996) menyatakan jumlah sisir per tandan dan jumlah buah per tandan dipengaruhi juga oleh genom dari tanaman.

Hal ini menunjukkan bahwa pemberian pupuk guano dapat memperbaiki kesuburan tanah, pupuk guano mengandung 7$17 \% \mathrm{~N}, 8-15 \% \mathrm{P}$, dan $1,5-2,5 \% \mathrm{~K}$. N sangat dibutuhkan tanaman untuk mendukung pertumbuhan vegetatif dan generative tanaman. Selanjutnya $\mathrm{P}$ merangsang pertumbuhan akar dan pembungaan, $\mathrm{K}$ terutama berperan untuk memperkuat jaringan tanaman terutama batang tanaman (Syofiani dan Oktabriana, 2017).

\section{Umur Panen}

Berdasarkan hasil analisis tanah podsolik di Desa Kambiyain Kecamatan Tebing Tinggi Kabupaten Balangan. Kandungan $\mathrm{N}$ total 0,14 $\%$ rendah, dan hasil analisis pupuk guano menunjukan $\mathrm{N}$ total 3,713\% Tinggi, dan kebutuhan nitrogen bagi pertumbuhan generatif tanaman belum terpenuhi. Hal ini terjadi karena kemungkinan adanya ketidakseimbangan antara fase vegetatif dan generatif . Pada fase vegetatif membutuhkan $\mathrm{N}$ 
relatif tinggi dibandingkan $\mathrm{P}$ dan $\mathrm{K}$. Jadi Kandungan $\mathrm{N}$ dalam tanah sudah tidak tersedia/berkurang bagi pertumbuuhan tanaman generatif. Pemberian bahan organik ke dalam tanah akan mengalami penguraian dan membebaskan N.

Kekurangan unsur hara $\mathrm{N}$ akan mengganggu pertumbuhan tanaman, selain itu juga kekurangan unsur $\mathrm{N}$ tidak dapat memenuhi kebutuhan tanaman untuk mencapai tingkat produksi yang optimal sehingga pertumbuhan tanaman juga akan terganggu (Rochmadhona, 2017).

Pemupukan yang tersedia terutama pupuk nitrogen akan mempertinggi pertumbuhan vegetatif tanaman. Tanaman yang kekurangan unsur nitrogen mengalami hambatan dalam pembentukan hijau daun yang sangat berperan dalam fotosintesis, sehingga pembentukan karbohidrat yang berfungsi untuk energi dan pembentukan sel bagi pertumbuhan tanaman menjadi kurang akibatnya tanaman menjadi kuning dan pertumbuhan lambat yang memyebabkan umur panen menjadi lamabat (Mardianto, 2014 dalam Syofiani dan Oktabriana, 2017).

Salah satu alternatif untuk meningkatkan efisiensi pupuk $\mathrm{N}$ adalah dengan mempertahankan kondisi tanaman dalam keadaan cukup hara $\mathrm{N}$ namun tidak berlebihan.. Pemberian pupuk $\mathrm{N}$ ke dalam tanah harus memperhatikan status hara serta kebutuhan tanaman untuk mencapai hasil yang optimal (Nugroho, 2015).

Faktor-faktor yang menentukan umur panen. Masih banyak faktor lain yang perlu diperhatikan karena pengaruhnya cukup besar terhadap umur panen, antara lain: (1) kesuburan tanah, dimana tanah yang terlalu subur terutama kandungan unsur $\mathrm{N}$ tinggi akan mempercepat panen; (2) kandungan air dalam tanah dan kelembaban udara, tanaman yang tumbuh pada kondisi basah akan terpacu dominasi pertumbuhan vegetatifnya dari pada yang tumbuh pada kondisi kering; dan (c) radiasi matahari, kaitannya dengan panjang hari akan berpengaruh pada inisiasi pembungaan yang pada akhirnya mempengaruhi umur panen (Bobisanjaya, 2017).

\section{KESIMPULAN}

Pertumbuhan tinggi tanaman umur 2, 3 dan 4 BST; jumlah daun umur 4 BST; diameter batang umur 2, 3 dan 4 memperlihatkan respon terhadap pertumbuhan tanaman pisang muli terhadap berbagai dosis pupuk guano pada lahan podsolik. Pada perumbuhan generatif hanya berpengaruh pada banyak buah per sisir, sedangkan pada waktu berbunga, umur panen, panjang tandan dan banyak sisir tidak memberikan respon terhadap pemberian berbagai dosis pupuk guano pada lahan podsolik. Didapatkan dosis terbaik pupuk guano yaitu $\mathrm{g}_{4}\left(25\right.$ ton. $\left.\mathrm{ha}^{-1}\right)$ untuk pertumbuhan tanaman pisang mauli di lahan podsolik.

\section{UCAPAN TERIMAKASIH}

Kepada Dirbelmawa Kemenristekdikti Cq. LL Dikti Wilayah XI Kalimantan atas pembiayaan penelitian ini melalui Program Kreativitas Mahasiswa bidang Penelitian Eksakta dengan Nomor 917/L11/KM/2019 Tanggal 15 Mei 2019.

\section{DAFTAR PUSTAKA}

Afandi, F. N., Bambang, S. Dan Yulia, N. 2015. Pengaruh pemberian berbagai jenis bahan organik terhadap sifat kimia tanah pada pertumbuhan dan produksi tanaman ubi jalar di entisol Ngrangkah Pawon, Kediri. Jurnal Tanah dan Sumberdaya Lahan Vol 2 No. 2 Hal: 237-244.

Amrizal, Arif. 2014. Effect of the organic fertilizers guano and tithonia (Tithoniadiversifolia) on the growth 
and yield of sweet corn (Zea mays saccharata Sturt). http://repository.unand.ac.id. Diakses tanggal 13 November 2018.

BPS Kabupaten Balangan. 2015. Kabupaten Balangan Dalam Angka Tahun 2014. Paringin.

Gardner, F.P., Pearce R.B dan Mitchell R.L. 1991. Fisiologi Tanaman Budidaya. Penerbit Universitas Indonesia. Jakarta.

Hanafiah, K.A. 2002. Rancangan Percobaan. PT Raja Grafindo Persada. Jakarta.

Kan, K. 2106. Pisang Mas Dengan Segudang Manfaatnya. https://milemurian165.blogspot.com. Diakses tanggal 19 Desember 2018.

Makhtaruddin,. Sufardi dan Ashabul, A. 2015. Penggunaan guano dan pupuk NPK Mutiara untuk memperbaiki kualitas media subsoil dan pertumbuhan bibit kelapa sawit (elaeis guineensis jacq.). http://jurnal.unsyiah.ac.id/. Diakses tanggal 21 Desember 2018.

Marpaung, E. Agustina. 2014. Pemanfaatan pupuk organik padat dan organik cair dengan pengurangan pupuk anorganik terhadap pertumbuhan tanaman jagung (Zea mayz L). Jurnal Saintech Vol. 06 No. 04 Desember 2014.

Metro7 co.id. 2018. Balitbangda Kembangkan Pupuk Guano. https://metro7.co.id/?p=12072. Diakses Tanggal 05 Januri 2019.

Nurhasby,. Komar T.E dan Sumbayak E.S.S. Manual Monitoring Musim BerbungaBerbuah dan Produksi Buah Ramin
(Gonytylus bancanus). CV. Biografika. Bogor.

Prahasta, A. 2009. Agribisnis Pisang. CV Pustaka Grafika. Bandung.

Prihatini, S. 2012. Pengaruh Pupuk Terhadap Pertumbuhan Vegetatif Tanaman Pisang (Musa Paradisiaca) Di Lahan Kering. $\quad$ https://elisa.ugm.ac.id/. Diakses tanggal 14 April 2019.

Puspadewi, S., W. Sutarti dan Kusumiyati. 2016. Pengaruh konsentrasi pupuk organik cair (POC) dan dosis pupuk $N$, $P, K$ terhadap pertumbuhan dan hasil tanaman jagung manis (Zea mays L. var Rugosa Bonaf) kultivar Talenta. Jurnal Kultivasi Vol. 15(3) Desember 2016.

Putro, M.A., 2008. Pengaruh Kalium Terhadap Pertumbuhan Pisang Raja Bulu (Musa Sp. Aab Group) Di Bogor, Jawa Barat. https://repository.ipb.ac.id/. Diakses tanggal 14 April 2019

Rochmadhona, V.U. 2017. Pengaruh pemberian pupuk organik terhadap hasil panen dan daya simpan buah naga merah (Hylocereus polyrhizus) sebagai desain sumber belajar Biologi $S M A$. Jurnal Lentera Vol. 2. No. 1, Juni 2017.

Sipendik Team, 2014. Cara Praktis Budidaya Pisang untuk Hasil Panen Berlimpah. https://www.sipendik.com/. Diakses tanggal 13 April 2019.

Sutedjo, M.M. 2010. Pupuk dan Cara Pemupukan. PT Rineka Cipta. Jakarta. 
Suyanti dan Ahmad, S. 2008. Budidaya Pisang, Pengolahan, dan Prospek Pasar. Penebar Swadaya. Jakarta.

Soverda, N., Renaldy dan Susanti, I. 2008. Pengaruh beberapa macam bokashi terhadap pertumbuhan dan hasil tanaman tomat (Lycopersicon esculintum Mill) di Polybag. http://portalgarauda.org/. Diakses tanggal 05 November 2018.

Syofiani, R., dan Giska, O. 2017. Aplikasi pupuk guano dalam meningkatkan unsur hara $n, p, k$ dan pertumbuhan tanaman kedelai pada media tanam tailing tambang emas. https://jurnal.umj.ac.id/._Diakses tanggal 13 November 2018.

Sukaryorini, P., Ayu, M. F., dan Setyobudi, S. 2016. Pengaruh macam bahan organik terhadap ketersediaan amonium $\left(\mathrm{NH}^{+}\right)$,
C-organik dan populasi mikroorganisme pada tanah entisol. Plumula Volume 5 No. 2 Juli 2016.

Tim Bina Karya Tani. 2008. Pedoman Bertanam Pisang. CV. Yrama Widya. Bandung.

Torus, B. 2012. Peranan Unsur Fosfor (P) Pada Pertanian. http://allaboutpertanian.blogspot.com/. Diakses tanggal 13 April 2019.

Wahida dan Suryaninsih, N. L. S. 2016. Analisis kandungan unsur hara pupuk organik cair dari limbah rumah tangga di Kabupaten Merauke. Jurnal Agricola, Vol 6 (1), Maret 2016.

Wkipedia. 2016. Musa acuminata. https://id.wikipedia.org/wiki/. Diakses Tanggal 07 Desember 2018. 